\title{
Improve Capsicum spp. Seed Quality in Seedling Using Microorganism Organic Fertilizers
}

\author{
Faculty of Agriculture, Boyolali University \\ $J$. Pandanaran No 403, Winong, Boyolali \\ Email: praba@uby.ac.id
}

Jujuk Juhariah, Dwi Suci Lestariana, Margaretha Praba Aulia*

\begin{abstract}
Boyolali is famous with its livestock and agricultural products in both organic and conventional system. The farmer commonly cultivates horticulture commodity especially vegetable plants. One of the most popular horticulture products in Boyolali is chili (Capsicum spp.). Availability of ready to plant chili seed is one of factor to trigger the chili cultivation successful in Boyolali. To support the local farmers in producing organic chili, so a research to improve the organic chili seed quality in seedling is needed. This study aims to improve the seed quality in seedling using microorganism-based fertilizer. This study was conducted from July to September 2019 at Boyolali University's greenhouse. This experiment was an arranged factorial randomized block design with three factors, which are three chili varieties (green, white, and curly chili) and three kinds of organic fertilizers (microalgae, effective microorganisms, and local microorganisms). Chili seedling got three fertilizer treatments based on its experiment plot. Then the plants observed five times: seven days, 14 days, 21 days, 28 days, and 35 days after planting. Parameters observed are the living plant number, leaves' number, and plant height. The observation results were then tested by analysis of variance with the $F$ test at the $5 \%$ level. Then proceed with the honest real different test at the $5 \%$ level for the parameters that show significant differences. The results show that there was no significant difference in living plant numbers among all the treatments. The significant differences appear in the number of leaves and plant height. The significant difference indicated that the difference influenced by the plant type not because of the application of the fertilizer.
\end{abstract}

Keywords : Organic; chili, seed, fertilizers, microorganism

\section{INTRODUCTION}

Boyolali is a district in Central Java Province, which located in Merapi and Merbabu Mountain. This geographic condition makes Boyolali has high potential agriculture and animal husbandry. The famous livestock products from Boyolali are beef and milk that have good quality. Therefore, Boyolali also familiar with its horticulture and crops product that cultivated conventionally or organically.

Organic farming is a system that uses organic matter to do agricultural cultivation. Organic farming systems surely can make the plant grow better and produce more yield. The higher organic matter in the soil can improve soil structure, so it can increase the soil quality and the yield (Isnaini 2006 and Damaiyanti, et. al. 2013). Agricultural products from the organic farming system can increase continuously (Sutanto 2002). The organic farming system is sustainable agriculture because the organic matter in the soil can improve the soil quality and leaving no residue that can destroy the physical and chemical characteristics of the soil. However, conventional farming systems decrease the soil quality because of the chemical residues in the agricultural land.

Organic matters in the soil generate more fertile soil because it can fix the size of soil particle and soil texture. High organic matter also decreases the soil bulk density that makes the infiltration process and soil permeability better 
(Margolang et al., 2015 and Manopo, et. al. 2018). There are four principles as the fundamental of organic farming system (Aero 2011):Health principal, organic farming must be conserved and increase the health of the soil, plant, animal, human, and earth as a whole unit. The ecological principle, organic farming should be based on the ecological system of life, work, imitate, and try to maintain the life ecological system and cycle. Equity principal, organic farming have to build a relationship that can ensure fairness related to the environment and the opportunity to live together. Protection principal, organic farming must be managed carefully and responsibly to protect the health and prosperity of people who life now and the future life and also the environment.

Chili (Capsicum spp.) is an important horticulture commodity because of its economic value. To get the optimum yield and profit of chili cultivation, the farmers have to take into account the seed quality. The way to choose the seed and seeding process plays an important rule in cultivating chili. The farmer should choose a certified seed and do the seeding process appropriately. An appropriate seeding process can produce a good and healthy chili plant. Chili seed is a result of extraction from chili that qualified to be a seed. Chili should be harvested when it has a physiological ripe perfectly. The fruit that physiologically ripe can produce high vigor seed (Pitojo 2007). A physiologically ripe chili and fulfill the criteria of seed then extracted to get the chili seed. The aims of extraction are: to get the clean seed, separated from the fruit and the other plant parts, and free from the inhibiting agent in the surface of the seeds (Salam 2010).

In Indonesia, the seed must fulfill the criteria based on SNI 01-7006-2004 about the chili seed. After the seed placed into an optimum media to grow, the chili seed started to have metabolism activities. Chili has an epigeal type of germination which is the seed section that appears to the soil surface and the roots inside the soil (Asih et al., 2003 and Mujiyono et.al. 2018).

Seedling is the initial process of chili cultivation to get a healthy and strong plant. In general, seedling media to grow the chili seed is the mixture of soil, manure, TSP or NPK, and Insecticide powder (Prajnanta 2009 and Han, et. al.
2016). However, in organic farming, the farmer cannot use the chemical component in cultivation since the seedling process. The microorganism is the right choice to help the farmer produce a high-quality plant that can reach the optimum yield.

Microorganism activities cannot separate from the organic farming system. Fungus, bacteria, viruses, and nematodes are the most common microorganisms used by the farmers as the fertilizer or as the pest controller. Besides that, microorganisms can be used as bio decomposers and plant growth substances (Nurhayati and Irreng, 2014 and Safitri et. al. 2017). Microorganisms as biofertilizer can help to provide nitrogen in the soil (Rhizobium, Azospirillum, and Azotobacter), Phosphate (phosphate solvents bacteria, ectomycorrhizae, and mycorrhizae vesicular arbuscular), and trigger the decomposition process of organic matter (cellulose breaker and effective microorganism) (Rahmawati 2006). Another kind of microorganism can be used as fertilizer is microalgae. Microalgae is a photosynthetic organisms constitute eukaryotic green algae and Gram-negative prokaryotic cyanobacteria. In modern agriculture, microalgae can improve the nutrient availability, maintain the organic carbon as a result of soil microbial activity (Renuka, et.al. 2018). Microalgae can apply in good agriculture practice or organic farming (Uysal, et.al. 2015 and Cenciani et. al. 2011).

The use of microorganism-based organic fertilizers is one of the ways that can use to improve the chili seedling quality organically. Organic fertilizer uses in the organic nursery is an initial step to support organic farming particularly in chili commodities. Organic agriculture that started famous among society has to get support from stakeholders. Besides that, the seed producers must prepare the certified organic seed to support the organic farming system. In common, organic fertilizer available in the public market is a microorganism-based organic fertilizer, which uses microorganisms' activity to support the plant growth. Based on the information carried, the basic research about organic seedling is needed to support the organic farming system in Indonesia. 


\section{MATERIAL AND METHODS}

The study was conducted from July to August 2019. Research processes were conducted in Boyolali University Greenhouse, Boyolali, Central Java, Indonesia. The experiment was arranged in factorial randomized block design with three factors, which are three chili varieties (green, white, and curly chili) and three kinds of organic fertilizers (microalgae, effective microorganisms, and local microorganisms). There are nine treatment combinations and three replications, thus it can be found 27 treatment plots.

The chili seeds in the nursery got three fertilizer treatments based on the plot. Then observed seven days after planting, 14 days, 21 days, 28 days, and 35 days after planting process. Parameters observed were the number of living plants, number of leaves, and plant height. Data of Analysis of Variance (ANOVA) and means comparison was computed by excel software. Honest real difference test at 0.05 level was used to analyze significant differences in different treatments with probability $5 \%$.

\section{RESULTS AND DISCUSSIONS}

The average number of living plants in every treatment shows in table 1 . There is no significant difference among those treatments in both fertilizer type and chili varieties. In this research, the seed sample used a certified chili seed and in good packaging. So, the quality of seed is guaranteed. According to Copeland (1977) in Kartasapoetra (2003), packaging and shelf life influenced seed vigor. A high growth rate and vigor can be seen from the sprout or seed phenotype performance, further can be used as the basis of seed endurance to many stress.

Table 1. The averages of living plants number in the last observation.

\begin{tabular}{ccccc}
\hline \multirow{2}{*}{$\begin{array}{c}\text { Fertilizers } \\
\text { type }\end{array}$} & \multicolumn{3}{c}{ Chili varieties } & \multirow{2}{*}{ Average } \\
\cline { 2 - 4 } & $\mathrm{P}$ & $\mathrm{H}$ & $\mathrm{K}$ & \\
\hline A & 39.00 & 40.00 & 40.00 & 39.67 \\
B & 39.00 & 37.33 & 40.00 & 38.78 \\
C & 39.33 & 39.67 & 40.00 & 39.67 \\
\hline Average & 39.11 & 39.00 & 40.00 & \\
\hline
\end{tabular}

The insignificant difference among the treatments is provable by the histogram in figure 1 . Since the first observation, the number of the living plant is more than 30 from a maximum of 40 plants. Also, in the last observation, there are four treatments that all the plants are living that is $\mathrm{HA}, \mathrm{KA}, \mathrm{KB}$, and $K C$. So, all the chili variety with the code is $K$ alive until the last observation of the experiment. This can be influenced by the seed quality. Curly chili seed is the most expensive seed compared to the other varieties and the packaging is very good. As a result, the seed quality inside the package is guaranteed, produces the high quality of seedling, and has high vigor seed.

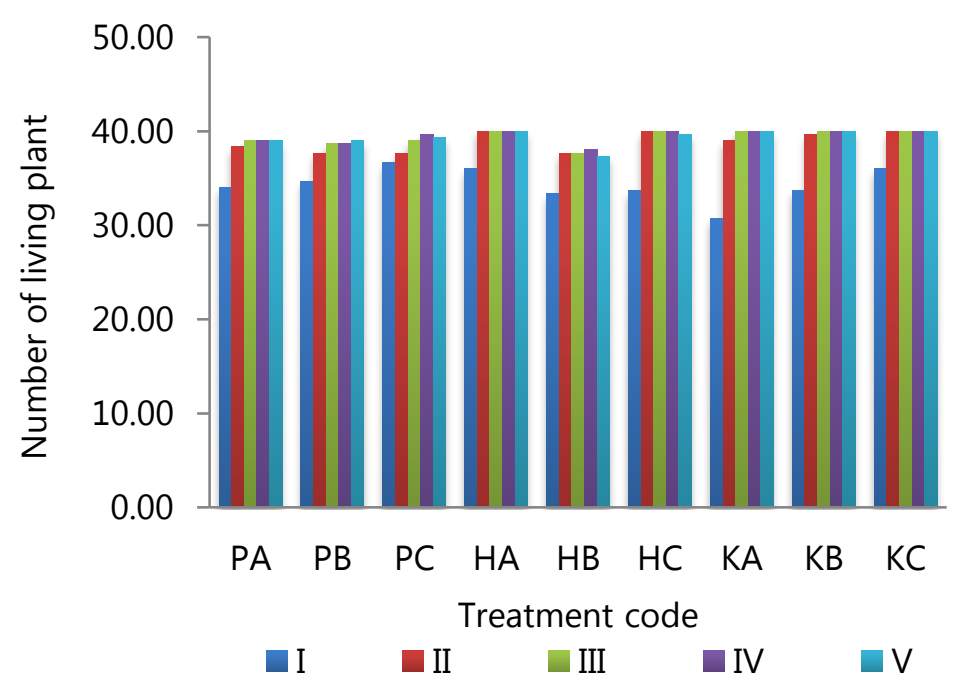

Figure 1. Comparison of the Average Number of living plants histogram 
Figure 2 shows the significant difference in plant height starts from the third observation. Height accretion speeds among the three varieties are different. Curly chili with the code is $\mathrm{K}$ has the highest accretion speeds compared to the other varieties in any type of fertilizer treatment and shows a significant difference. Table 2 shows it is significantly different in the source of diversity chili varieties based on honest real difference test at 0.05 levels. White chili with "P" code is not significantly different from the green chili " $\mathrm{H}$ " code because it followed by the same letter "a" in their average. However, the plant height average of curly chili with "K" code followed by a "c" letter. It proves that curly chili has the fastest speed in high accretion.

According to Marsono and Paulus (2005) and Han, et. al. (2016), Nitrogen plays important rules in stimulating growth in general particularly in vegetative phase nitrogen is important to produce chlorophyll, protein, fat, and other compounds. Phosphor works to boost the growth of roots, as the ingredients of making the protein that helps in the assimilation and respiration process. Potassium has the function of forming protein and carbohydrates, make the plant tissues stronger, and forming the plant antibody. Nevertheless, the fertilizer treatment did not give significant differences in any chili varieties. In seedling stadia, the plant does not optimally absorb nutrients from the fertilizer. Furthermore, the fertilizer is given organically and takes more time to change to become macronutrients and absorb properly.

Table 2. The averages of plant height in the last observation

\begin{tabular}{crrrr}
\hline Fertilizers & \multicolumn{3}{c}{ Chili varieties } & \multirow{2}{*}{ Average } \\
\cline { 2 - 4 } type & \multicolumn{1}{c}{$\mathrm{P}$} & \multicolumn{1}{c}{$\mathrm{K}$} & $\mathrm{H}$ & \\
\hline $\mathrm{A}$ & 6.70 & 11.72 & 6.17 & 8.20 \\
$\mathrm{~B}$ & 7.58 & 11.56 & 7.00 & 8.71 \\
$\mathrm{C}$ & 7.06 & 9.54 & 6.05 & 7.55 \\
\hline Average & $7.11 \mathrm{ab}$ & $10.94 \mathrm{c}$ & $6.41 \mathrm{a}$ & \\
\hline Note: Mean & followed by the & same letter are not \\
significantly different based on honest real difference \\
test at 0.05 levels
\end{tabular}

The average of leaves number starts from the first observation to the last observation showed in Figure 3. All of the treatments have the same trends as the average leaves number. Curly chili with the "K" code has the same trends in every observation time. Start from the second observation, curly chili has the highest leaves number. This condition supported by the plant height that curly chili is the highest plant compared to the other varieties.

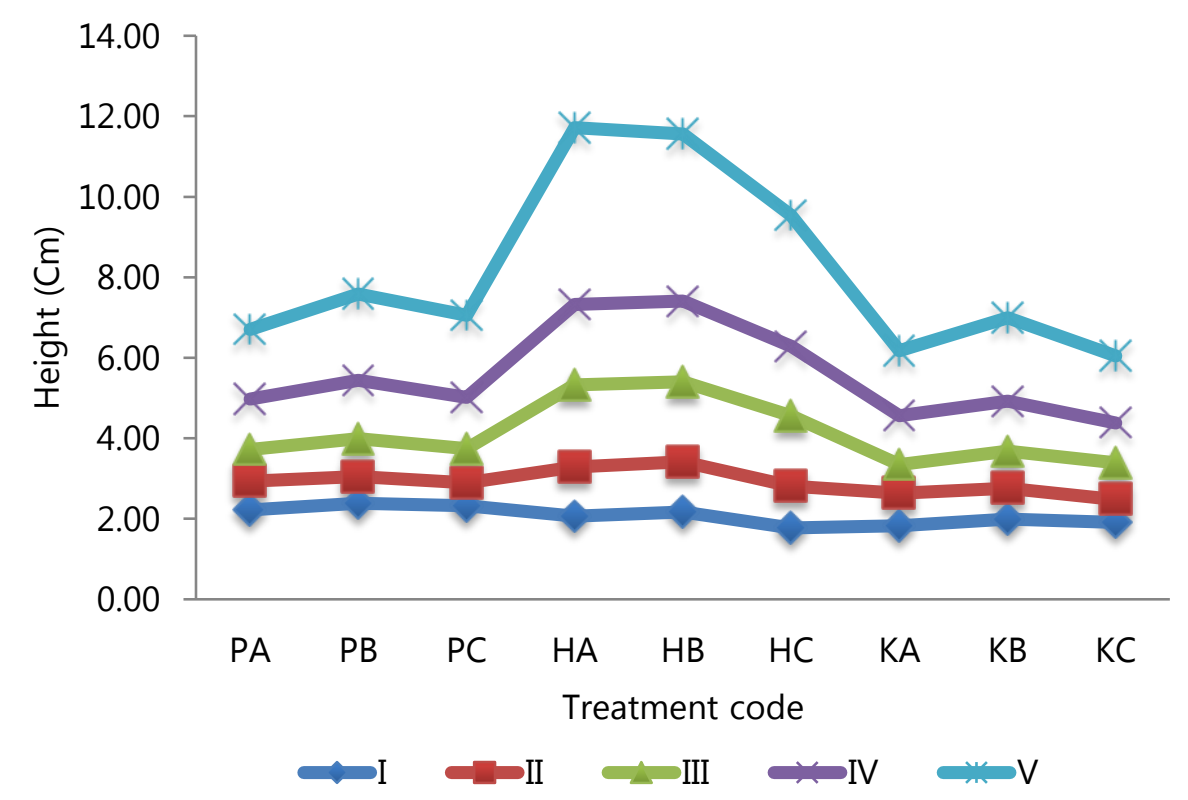

Figure 2. Graph of the Average Plant Height comparison 


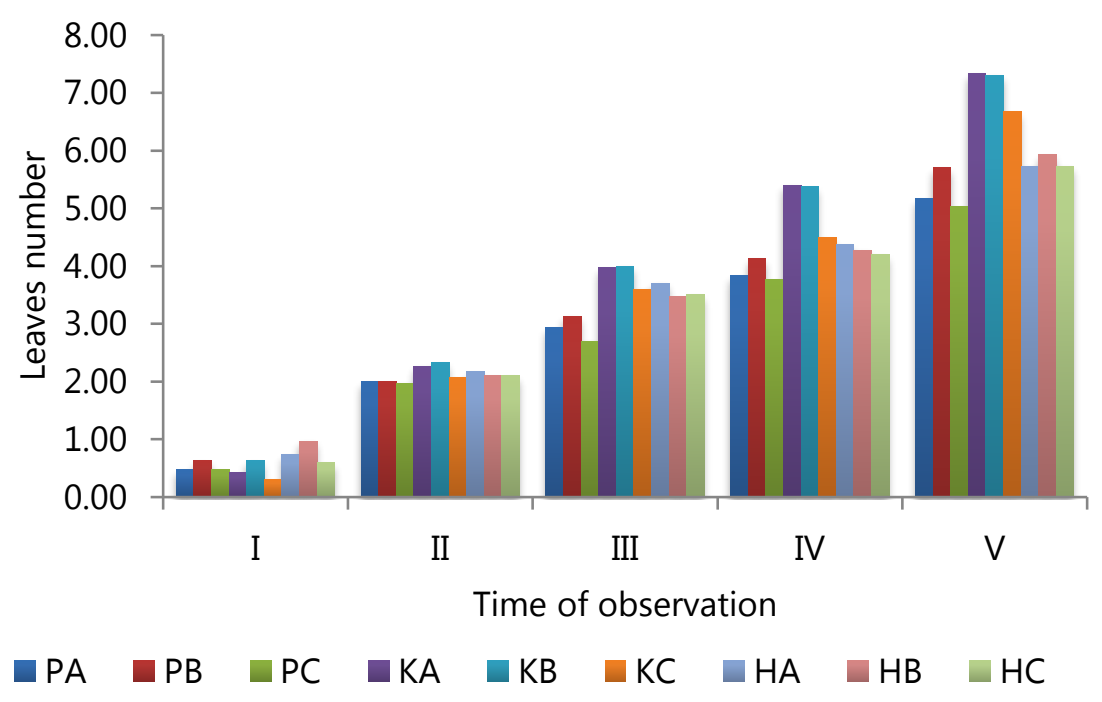

Figure 3. Comparison of the Average Number of leaves number histogram

Table 3. The averages of leaves number in the last observation

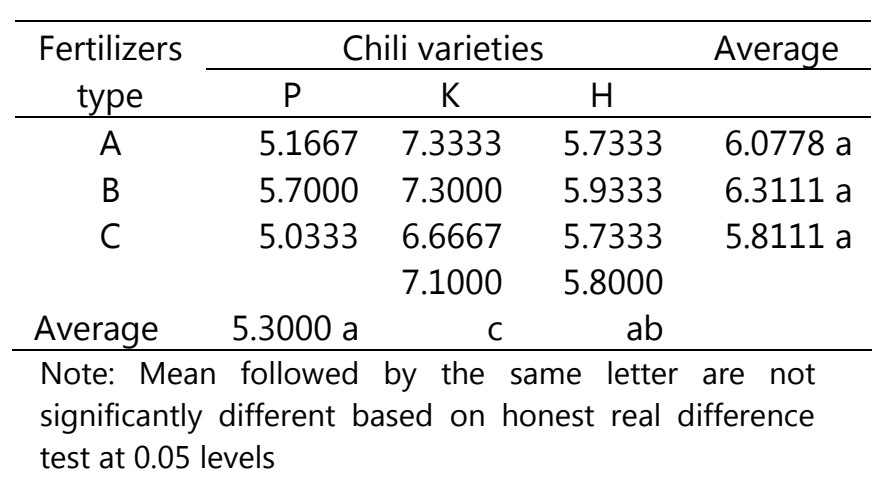

The significant difference in the averages of leaves number in the last observation stated in table 3. Fertilizer types did not give a significant effect on every chili varieties. The leaves' number of white chili is not significantly different from green chili, but curly chili's leaves number is significantly different compared to the other varieties. It because curly chili has a taller plant type, so the leaves number also higher compared to the other varieties.

\section{CONCLUSION}

Microorganisms base organic fertilizer application did not give significant effects to living plant numbers in any chili varieties. Plant heights show the significant different start from the third observation and curly chili has the fastest height growth rate. The application of organic fertilizer did not give a significant effect on leaves' number while chili varieties show a significant difference in its parameter. Curly chili has the most leaves and tallest plant.

\section{REFERENCES}

Aero, W. 2011. Analisis Keberlanjutan Praktik Pertanian Organik di Kalangan Petani, Institut Pertanian Bogor, Bogor.

Asih, N., Abdjad, H., Purwanto, I., \& Wahyudi, A. 2003, Cabai Hot Beauty. Penebar Swadaya, Jakarta.

Cenciani, K, Bittencourt-Olivera, M, C, Feigl, B, J \& Cerri, C, C 2011, Sustainable production of biodiesel by microalgae and its application in agriculture, African Journal of Microbiology Research, 5(26):4638-4645.

Damaiyanti, D.R.R., Aini, N. \& Koesriharti. 2013. Kajian penggunaan macam mulsa organik pada pertumbuhan dan hasil tanaman cabai besar (Capsicum annuum L.), Jurnal Produksi Tanaman, 1(2):25-32.

Han, S.H., An, J.Y., Hwang, J., Kim, S.B. \& Park, B.B. 2016. The effects of organic manure and chemical fertilizer on the growth and nutrient concentrations of yellow poplar (Liriodendron tulipfera Lin.) in a nursery system. Forest science and technology, 12(3):137-143.

Isnaini, M 2006, Pertanian Organik. Kreasi Wacana. Yogyakarta. 
Kartasapoetra, A.G. 2003. Teknologi Benih: Pengolahan Benih dan Tuntunan Praktikum, Rineka Cipta, Jakarta.

Manopo, J.S.S. Sakul, E.H. \& Karundeng, M. 2018. Penggunaan pupuk organik untuk meningkatkan hasil tanaman cabai kelompok tani di Kabupaten Minahasa. Jurnal dedikasi, 20(1):95-100.

Margolang, R. D., Jamilah, \& Sembiring, M. 2015. Karakteristik Beberapa Sifat Fisik, Kimia, dan Biologi Tanah pada Sistem Pertanian Organik. Jurnal Agroteknologi, 3(2):717-723.

Marsono \& Paulus, S. 2005. Pupuk Akar Jenis dan Aplikasinya, Penebar Swadaya, Jakarta.

Mujiyo, Sumarno, Suryono, \& Sutopo, N. R 2018, Aplikasi pupuk organik diperkaya mikrobia pada usaha pembibitan tanaman. Journal of community empowering a services, 2(2):44-49.

Nurhayati, H. \& Ireng, D. 2014, Peran Mikroorganisme dalam Mendukung Pertanian Organik, Pros. Sem. Nas, Pertanian Organik, 295-300, Bogor.

Pitojo, S. 2007. Benih Cabai, Kanisius, Yogyakarta.

Prajnanta, F. 2009. Agribisnis Cabai Hibrida.
Penebar Swadaya, Jakarta.

Rahmawati, N. 2006. Pemanfaatan Biofertilizer pada Pertanian Organik. USU Repository, Medan.

Renuka, N., Guldhe, A., Prasanna, R., Singh, P. \& Bux, F. 2018, Microalgae as multi-functional options in modern agriculture: current trends, prospects and challenges. Biotecnology Advances. 36(4):1255-1273.

Safitri, A.D., Linda, R. \& Rahmawati. 2017. Aplikasi pupuk organik cair (POC) kotoran kambing difermentasikan dengan EM4 terhadap pertumbuhan dan produktivitas tanaman cabai rawit (Capsicum frutescents L.) Var. Bara. Protobiont, 6(3):182-287.

Salam, A 2010, Pengolahan Benih, Disampaikan pada kuliah pengantar produksi benih di PPPPTK Pertanian Cianjur, Tidak di Publikasikan.

Sutanto, R. 2002. Penerapan Pertanian Organik, Kanisius, Yogyakarta.

Uysal, O., Uysal, F.O. \& Ekinci, K. 2015. Evaluation of microalgae as microbial fertilizer, European Journal of Sustainable Development. 4(2):77-82. 